\title{
The Role and Fate of Rabbit and Human Transcobalamin II in the Plasma Transport of Vitamin $B_{12}$ in the Rabbit
}

\author{
Robert J. Schnemer, Robert L. Burger, Carol S. Mehlman, and \\ Robert H. Allen \\ From the Divisions of Hematology and Oncology, Department of Internal \\ Medicine, Washington University School of Medicine, \\ St. Louis, Missouri 63110
}

\begin{abstract}
A B S T R A C T Previous studies have shown that plasma transcobalamin II (TCII) facilitates the cellular uptake of $\left[{ }^{57} \mathrm{Co}\right]$ vitamin $\mathrm{B}_{12}\left(\mathrm{~B}_{12}\right)$ by a variety of tissues, but the lack of an intrinsic label on the protein moiety of the TCII-B 12 complex has made it impossible to determine the role and fate of TCII during this process. We have labeled homogeneous rabbit and human TCII with ${ }^{125}$ I-labeled $N$-succinimidyl-3-(4-hydroxyphenyl) propionate and have performed in vivo experiments in rabbits.

When ${ }^{120} \mathrm{I}$-labeled rabbit TCII- $\left[{ }^{87} \mathrm{Co}\right] \mathrm{B}_{12}$ and ${ }^{101} \mathrm{I}-\mathrm{la}-$ beled bovine albumin were simultaneously injected intravenously, we observed that ${ }^{125} \mathrm{I}$ and ${ }^{87} \mathrm{Co}$ were cleared from plasma at a faster rate $\left(t_{1}=1 \frac{1}{2} h\right)$ than ${ }^{201} I$ and that ${ }^{125} \mathrm{I}$ and ${ }^{57} \mathrm{Co}$ were present in excess of ${ }^{181} \mathrm{I}$ in the kidney, liver, spleen, heart, lung, and small intestine $\frac{1}{2} \mathrm{~h}$ after injection. Later, ${ }^{87} \mathrm{Co}$ remained in excess of ${ }^{181} \mathrm{I}$, but the ratio of ${ }^{125} \mathrm{I}$ to ${ }^{121} \mathrm{I}$ decreased progressively in all of these tissues; ${ }^{10} \mathrm{I}$ fragments ( $\mathrm{mol}$ wt less than $1,000)$ appeared in the plasma and were rapidly excreted in the urine. After $1 \mathrm{~h}$ following injection, ${ }^{57} \mathrm{Co}$ was present in excess of ${ }^{125} \mathrm{I}$ in the plasma. Additional experiments revealed that both isotopic moieties of human TCII-B were cleared from rabbit plasma $30 \%$ faster than their rabbit TCII-B1s counterparts and that apo-rabbit TCII and apo-human TCII were cleared from rabbit plasma $30 \%$ faster than holo-rabbit TCII and holo-human TCII, respectively.
\end{abstract}

These studies, and appropriate control experiments, indicate that TCII and the TCII- $\mathrm{B}_{12}$ complex are cleared

This work was presented in part at the Annual Meeting of the American Society of Hematology, Atlanta, Ga., 9 December 1974. A preliminary report has appeared in abstract form (1).

Dr. Allen is the recipient of Faculty Research Award (FRA 122) from the American Cancer Society.

Received for publication 14 March 1975 and in revised form 5 September 1975. from plasma by a variety of tissues, that the TCII moiety is degraded during this process, and that a significant portion of the $B_{12}$ recirculates.

\section{INTRODUCTION}

Human plasma contains three vitamin $\mathrm{B}_{12}\left(\mathrm{~B}_{12}\right)^{1}$-binding proteins, referred to (2-6) as transcobalamin I (TCI), transcobalamin II (TCII), and transcobalamin III (TCIII). TCI and TCIII are glycoproteins and belong to the group of immunologically similar proteins known as the $\mathrm{R}$-type $\mathrm{B}_{12}$-binding proteins (6-10). Approximately $70-90 \%$ of the endogenous $B_{1 s}$ in human plasma is bound to TCI $(6,11)$, but $\left[{ }^{57} \mathrm{Co}\right] \mathrm{B}_{1}$ bound to TCI is cleared slowly from human plasma with a $t_{1}$ of 9-12 days (12). TCIII is derived from granulocytes $(2,6)$, contains less sialic acid than TCI (6), and appears to circulate in vivo at a barely detectable level, less than $30 \%$ that of TCI $(2,6)$. Both moieties of ${ }^{125} \mathrm{I}$-labeled human TCIII- $\left[{ }^{57} \mathrm{Co}\right] \mathrm{B}_{1 \mathrm{~s}}$ are cleared rapidly $\left(\mathrm{t}_{1}<5 \mathrm{~min}\right.$ ) from rabbit plasma by the liver (13) by the mechanism described by Ashwell and Morell (14) for the clearance and catabolism of a wide variety of asialoglycoproteins. This observation suggests that TCIII might serve a scavenger function for $B_{1}$ released into areas of cell necrosis or infection. This function is compatible with the lack of any hematologic abnormalities in two brothers with apparent congenital deficiencies of all R-type $B_{12}$-binding proteins (15).

TCII is not a glycoprotein (5) and is immunologically distinct from the R-type proteins (4). TCII facilitates the cellular uptake of $\left[{ }^{57} \mathrm{Co}\right] \mathrm{B}_{\mathbf{s}}$ by a variety of cells in vitro (16-20), and a congenital deficiency of this protein results in a severe megaloblastic anemia that re-

\footnotetext{
${ }^{1}$ Abbreviations used in this paper: $\mathrm{B}_{12}$, vitamin $\mathrm{B}_{12}$; TCI, transcobalamin I; TCII, transcobalamin II ; TCIII, transcobalamin III.
} 
sponds only to large frequent injections of $\mathrm{B}_{12}$ (21). TCII contains only $10-20 \%(6,11)$ of the endogenous $\mathrm{B}_{12}$ in human plasma, but approximately $70 \%$ of $\left[{ }^{57} \mathrm{Co}\right] \mathrm{B}_{12}$ bound to human TCII is cleared from human plasma in the $10 \mathrm{~min}$ after injection (12). During the following hours, $t_{1}$ values for clearance have been estimated in the range of $1 \mathrm{~h} \mathrm{(22)}$ to $12 \mathrm{~h} \mathrm{(12).} \mathrm{The} \mathrm{lack} \mathrm{of} \mathrm{a}$ label on the protein moiety of TCII- $\mathrm{B}_{12}$ has made it impossible to determine whether the early rapid plasma clearance of $\left[{ }^{57} \mathrm{Co}\right] \mathrm{B}_{12}$ is due to an unusually large extracellular fluid distribution of TCII- $\left[{ }^{57} \mathrm{Co}\right] \mathrm{B}_{12}$ or whether the slow, late clearance of $\left[{ }^{57} \mathrm{Co}\right] \mathrm{B}_{12}$ is due to recirculation of the $\left[{ }^{57} \mathrm{Co}\right] \mathrm{B}_{12}$ molecule. To elucidate the role and fate of TCII in the plasma transport of $\mathrm{B}_{12}$, we have labeled rabbit and human TCII with ${ }^{125} \mathrm{I}$ and have studied the plasma clearances of these proteins in the presence and absence of $\left[{ }^{67} \mathrm{Co}\right] \mathrm{B}_{12}$ in rabbits.

\section{METHODS}

Protein preparations. Human TCII was isolated from Cohn fraction III of normal human plasma, as described previously (5), except that the preparation employed here was isolated from a different batch of Cohn fraction III. When a $20 \mu \mathrm{g}$ of this second preparation of human TCII was subjected to sodium dodecyl sulfate polyacrylamide gel electrophoresis in the presence of $1 \%$ 2-mercaptoethanol, a single protein band was observed, with an apparent mol wt of 38,000 . This differs from the original preparation, which gave two protein bands with apparent mol wts of 38,000 and 25,000 (5). The significance of this difference will be discussed elsewhere. ${ }^{2}$ The two preparations were otherwise identical in terms of amino acid composition, amino acid content relative to $B_{12}$, lack of carbohydrate, absorption spectra, apparent $\mathrm{mol} \mathrm{wt}(38,000)$ based on gel filtration at low TCII concentrations $(<10 \mu \mathrm{g} / \mathrm{ml})$, yield $(15 \%)$, and overall purification $(2,000,000$-fold relative to plasma).

Rabbit TCII was isolated from 20 liters of rabbit serum (type 2 from 1-3-yr-old rabbits, Pel-Freez Bio-Animals, Inc., Rogers, Ark.) by a purification scheme consisting of affinity chromatography on $\mathrm{B}_{12}$-Sepharose, chromatography on DEAE-cellulose, and gel filtration on Sephadex G-150. These purification techniques were performed essentially as described for human TCII (5), and details will be presented elsewhere. ${ }^{2}$ The final preparation was purified 40,000 -fold relative to serum, with a yield of $31 \%$, and gave a single band on sodium dodecyl sulfate polyacrylamide gel electrophoresis with an apparent mol wt of 40,000. Purified rabbit TCII gave a single precipitin line on immunodiffusion against chicken anti-human TCII with a pattern of partial identity to human TCII.

Labeling of proteins with ${ }^{125} I$ and ${ }^{181} I . \quad N$-Succinimidyl 3(4-hydroxyphenyl) propionate (Pierce Chemical Co., Rockford, Ill.) was labeled with ${ }^{225} \mathrm{I}$ and ${ }^{131} \mathrm{I}$ (carrier-free, 50$200 \mathrm{mCi} / \mathrm{ml}$, Mallinckrodt Chemical Works, St. Louis, Mo.) by a modification of the method of Bolton and Hunter (23). The following components were added sequentially at 5-10-s intervals at room temperature to a test tube that contained $2.5 \mu \mathrm{g}$ of dry $\mathrm{N}$-succinimidyl 3-(4-hydroxyphenyl) propionate: (a) $9.6 \mathrm{mCi}$ of $\mathrm{Na}^{125} \mathrm{I}$ in $150 \mu \mathrm{l}$ of $\mathrm{H}_{2} \mathrm{O}$; (b) $250 \mu \mathrm{g}$

${ }^{2}$ Allen, R. H., R. J. Schneider, R. L. Burger, and C. S. Mehlman. Manuscript in preparation. of chloramine $\mathrm{T}$ in $50 \mu \mathrm{l}$ of $0.25 \mathrm{M}$ potassium phosphate, $\mathrm{pH} 7.5 ;$ (c) $600 \mu \mathrm{g}$ of sodium metabisulfite in $50 \mu \mathrm{l}$ of $0.05 \mathrm{M}$ potassium phosphate, $\mathrm{pH} 7.5,(d) 1 \mathrm{mg}$ of $\mathrm{KI}$ in $50 \mu 1$ of $0.05 \mathrm{M}$ potassium phosphate, $\mathrm{pH} 7.5$; and $(e) 25$ $\mu 1$ of dimethylformamide. The solution was extracted rapidly with two $0.5-\mathrm{ml}$ portions of benzene. The benzene extracts were combined, divided into aliquots, and dried by a stream of nitrogen. Approximately $0.21 \mathrm{~mol}$ of ${ }^{125} \mathrm{I}$ were coupled per mol of ester, if all of the ester and none of the free ${ }^{225}$ I was recovered in the benzene extract.

Rabbit TCII (approximately $25 \mu \mathrm{g}$ of protein saturated with $0.75 \mu \mathrm{g}$ of bound $\mathrm{B}_{12}$ ) in $75 \mu \mathrm{l}$ of $0.1 \mathrm{M}$ boric acid$\mathrm{KOH}, \mathrm{pH} 8.5,0.75 \mathrm{M} \mathrm{NaCl}$, was added to $0.75 \mu \mathrm{g}$ of the dried, ${ }^{125}$ I-labeled ester, and the reaction mixture was gently agitated at $4^{\circ} \mathrm{C}$. After $15 \mathrm{~min}, 200 \mu 1$ of $0.2 \mathrm{M}$ glycine in $0.1 \mathrm{M}$ boric acid- $\mathrm{KOH}, \mathrm{pH} 8.5$, was added, before an additional $5 \mathrm{~min}$ of agitation. Gelatin (type I, Sigma Chemical Co., Inc., St. Louis, Mo.), $2.5 \mathrm{mg}$ in $1.0 \mathrm{ml}$ of $0.05 \mathrm{M}$ potassium phosphate, $\mathrm{pH} 7.5,0.75 \mathrm{M} \mathrm{NaCl}$ was added to reduce the adsorption of ${ }^{125} \mathrm{I}$-labeled rabbit TCII to dialysis tubing, and the sample was dialyzed for $24 \mathrm{~h}$ at $4^{\circ} \mathrm{C}$ against 1.2 liters of $0.05 \mathrm{M}$ potassium phosphate, $\mathrm{pH} 7.5,0.75 \mathrm{M}$ $\mathrm{NaCl}$, with a dialysate change after $19 \mathrm{~h}$. Human TCII (approximately $16 \mu \mathrm{g}$ of protein saturated with $0.50 \mu \mathrm{g}$ of bound $\mathrm{B}_{12}$ ) was incubated with $0.5 \mu \mathrm{g}$ of the same preparation of ${ }^{125}$ I-labeled ester in a volume of $50 \mu 1 .{ }^{131}$ I-labeled ester was prepared as described above for the ${ }^{125} \mathrm{I}$-labeled ester. Approximately $0.20 \mathrm{~mol}$ of ${ }^{131} \mathrm{I}$ was coupled per mol of ester. Rabbit TCII and human TCII were labeled with ${ }^{131}$ I-labeled ester as described above for ${ }^{125} \mathrm{I}$. Bovine serum albumin (type V, Sigma Chemical Co.), $5 \mu \mathrm{g}$, was incubated with $0.25 \mu \mathrm{g}$ of ${ }^{131}$ I-labeled ester in a volume of $10 \mu \mathrm{l}$.

Removal and replacement of $B_{18}$. The low-specific-activity $\left[{ }^{57} \mathrm{Co}\right] \mathrm{B}_{12}(<0.03 \mu \mathrm{Ci} / \mu \mathrm{g})$, bound to ${ }^{125} \mathrm{I}$ and ${ }^{181} \mathrm{I}$-labeled rabbit and human TCII, was removed $(>99 \%)$ by dialysis of the entire sample at room temperature for $72 \mathrm{~h}$ against $15 \mathrm{vol}$ of $0.1 \mathrm{M}$ potassium phosphate, $\mathrm{pH} 7.5$, containing 7.5 M guanidine- $\mathrm{HCl}$, with dialysate changes after 24 and $48 \mathrm{~h}$. A twofold excess of high-specific-activity $\left[{ }^{57} \mathrm{Co}\right] \mathrm{B}_{12}$ $(15 \mu \mathrm{Ci} / \mu \mathrm{g}$ ) was added to aliquots of the dialyzed protein samples, and each sample was adjusted to contain $5.0 \mathrm{M}$ guanidine- $\mathrm{HCl}$ in a volume of $1.5 \mathrm{ml}$. The samples were then dialyzed against $550 \mathrm{ml}$ of $0.01 \mathrm{M}$ potassium phosphate, $\mathrm{pH} 7.5$, containing $0.14 \mathrm{M} \mathrm{NaCl}$ for $16 \mathrm{~h}$ at $4^{\circ} \mathrm{C}$. Thereafter, samples were adjusted to contain $0.25 \mathrm{mg}$ bovine serum albumin, $0.05 \mathrm{M}$ potassium phosphate, $\mathrm{pH} 7.5$, and $0.75 \mathrm{M} \mathrm{NaCl}$ in a volume of $2.5 \mathrm{ml}$ and were applied to a column $(2.0 \mathrm{~cm}$ diameter by $60 \mathrm{~cm}$ in height) of Sephadex G-150 equilibrated at $4^{\circ} \mathrm{C}$ with $0.05 \mathrm{M}$ potassium phosphate, $\mathrm{pH} 7.5$ and $0.75 \mathrm{M} \mathrm{NaCl}$. Fractions of $3.0 \mathrm{ml}$ were collected in glass test tubes that contained $300 \mu \mathrm{g}$ of bovine serum albumin in $150 \mu \mathrm{l}$ of equilibrating solution. The bovine serum albumin served to reduce the adsorption of ${ }^{125} \mathrm{I}$ - and ${ }^{131}$ I-labeled proteins to glass. Appropriate fractions (see "Results") were pooled and stored in 5-ml aliquots at $-20^{\circ}$. ${ }^{131}$ I-labeled rabbit and human TCII devoid of $B_{12}$ were prepared as just described, except that $\left[{ }^{57} \mathrm{Co}\right] \mathrm{B}_{12}$ was not added before the final dialysis step.

Experiments employing rabbits. Male New Zealand White rabbits, $1.9-2.9 \mathrm{~kg}$, (Ernest Elridge Rabbitry, St. Louis, Mo.) were fasted for $16 \mathrm{~h}$ before being used for experiments. Rabbits were restrained, and a continuous infusion $(0.2-0.8 \mathrm{ml} / \mathrm{min})$ of sterile $0.9 \% \mathrm{NaCl}$ was begun through a butterfly-short-25-pediatric infusion set (Abbott Laboratories, North Chicago, Ill.) inserted in the lateral ear vein and connected to a three-way stopcock. Rabbits were sedated by a single intravenous injection of pentobarbital 
( $25 \mathrm{mg} / \mathrm{kg}$ body wt). In experiments involving nephrectomy or ureteral ligation, the dose was increased by $50-100 \%$, and additional amounts were given as required to maintain sedation. The bladder was catherized with a number 8 French Foley pediatric catheter (The Kendall Co., Consumer Products Div., Chicago, Ill.). Radioactive protein samples $(2-4 \mathrm{ml}$ in $0.05 \mathrm{M}$ potassium phosphate, $\mathrm{pH} 7.5$ $0.75 \mathrm{M} \mathrm{NaCl}$ ) were mixed together in a counting vial (Poly Q vial, Beckman Instrument Co., Schiller Park, Ill.), taken up in a syringe, and injected intravenously through the three-way stopcock at time zero. Blood samples were obtained by puncture with a number 20 needle of the median artery of the ear not used for the infusion. Blood samples $(2-5 \mathrm{ml})$ were collected in $5-\mathrm{ml}$ Vacutainer tubes (Becton, Dickinson \& Co., Rutherford, N. J.) containing $7.2 \mathrm{mg}$ of $\mathrm{K}_{3} \mathrm{EDTA}$ and $0.01 \mathrm{mg}$ of potassium sorbate in $48 \mu \mathrm{l}$ of $\mathrm{H}_{2} \mathrm{O}$. Plasma was collected by centrifugation at $4,000 \mathrm{~g}$ for $10 \mathrm{~min}$ at $4^{\circ} \mathrm{C}$. There was no significant uptake or adsorption of any of the radioactive items by either blood cells or test tubes. Urine was collected at intervals by syringe aspirations of the bladder catheter. The bladder was rinsed with two $15-\mathrm{ml}$ vol of $0.9 \% \mathrm{NaCl}$ during each collection. Rabbits were killed by the rapid intravenous injection of $3 \mathrm{ml}$ of $0.9 \% \mathrm{NaCl}$ that contained $300 \mathrm{mg}$ of pentobarbitol. Death occurred within $15 \mathrm{~s}$. Organs were removed within $20 \mathrm{~min}$ after death and were rinsed lightly before being assayed for radioactivity.

Measurements of radioactivity. ${ }^{105} \mathrm{I},{ }^{181} \mathrm{I},{ }^{87} \mathrm{Co}$, and ${ }^{58} \mathrm{Co}$ were assayed with a Beckman G-300 three-channel gamma spectrometer (Beckman Instruments Inc., Fullerton, Calif.). Corrections were made for variations in counting efficiency, isotope spillover, and isotope decay. Spillover accounted for less than $10 \%$ of the total radioactivity measured for any particular isotope in any of the samples assayed. The amount of each isotope injected into a rabbit was calculated from the total volume of the sample and the measured concentration of the isotope. This value was corrected for the amount of each isotope that remained in the syringe and counting vial, as determined by direct assay of these items.

All samples were counted in the same type of plastic counting vials. This was important since the counting efficiency of ${ }^{125} \mathrm{I}$ varied by as much as $50 \%$ when the same sample was counted in various types of counting vials. Variations in counting efficiency were not noted with ${ }^{57} \mathrm{Co}$ ${ }^{88} \mathrm{Co}$, or ${ }^{131} \mathrm{I}$. Variation in the counting efficiency for ${ }^{128} \mathrm{I}$ was also noted with samples from different tissues, based on experiments in which ${ }^{125} \mathrm{I}$-labeled bovine serum albumin and ${ }^{131}$ I-labeled bovine serum albumin were simultaneously injected intravenously into rabbits. At $25 \mathrm{~min}$ after injection, the ratio of ${ }^{181} \mathrm{I}$ to ${ }^{128} \mathrm{I}$ in the plasma was within $1 \%$ of the preinjection ratio, but the ratio varied in various organs as follows: kidney, 1.31 ; liver, 1.15 ; spleen, 1.09 ; heart, 1.07; lung, 1.07; and small intestine, 1.09. These ratios varied by less than $3 \%$ in three rabbits that were studied. These ratios were used to correct the amount of ${ }^{125}$ I present in individual tissues in experiments in which other ${ }^{125} \mathrm{I}$-labeled proteins were studied.

Radioimmunoassay of human TCII. Test tubes contained the following: (a) $250 \mu \mathrm{l}$ of rabbit plasma, consisting of varying amounts of control plasma and control plasma containing human TCII-B $\mathrm{B}_{1 \mathrm{~s}}(0.25 \mu \mathrm{g}$ protein saturated with 8 $\mathrm{ng}$ of bound $\mathrm{B}_{12} / \mathrm{ml}$ of plasma); (b) $200 \mu \mathrm{l}$ of $0.1 \mathrm{M}$ potassium phosphate, $\mathrm{pH} 7.5,1.5 \mathrm{M} \mathrm{NaCl}$; (c) $25 \mu 1$ of 0.05 $\mathrm{M}$ potassium phosphate, $\mathrm{pH} 7.5,0.75 \mathrm{M} \mathrm{NaCl}$ containing ${ }^{125}$ I-labeled human TCII-B $\mathrm{B}_{12}$ (1 $\mathrm{ng}$ of protein, $33 \mathrm{pg} \mathrm{B}_{12}$ ), and $40 \mu \mathrm{g}$ of bovine serum albumin; and (d) $25 \mu \mathrm{l}$ of 0.05
M potassium phosphate, $\mathrm{pH} 7.5,0.75 \mathrm{M} \mathrm{NaCl}$, containing $0.3 \mu \mathrm{l}$ of rabbit anti-human TCII serum. After $17 \mathrm{~h}$ of gentle agitation at $4^{\circ} \mathrm{C}, 500 \mu \mathrm{l}$ of $0.05 \mathrm{M}$ potassium phosphate, $\mathrm{pH} 7.5,0.75 \mathrm{M} \mathrm{NaCl}$, containing $71 \mathrm{mg}$ of polyethylene glycol ( $\mathrm{mol} \mathrm{wt}=6000$, Union Carbide Corp., New York) was added. After standing for $15 \mathrm{~min}$, the tubes were centrifuged at $6,000 \mathrm{~g}$ for $15 \mathrm{~min}$, and $500 \mu \mathrm{l}$ of the supernatant liquid was assayed for ${ }^{120} \mathrm{I}$. Under these conditions, $60 \%$ of the ${ }^{125}$ I-labeled human TCII- $\mathrm{B}_{12}$ precipitated in the absence of unlabeled human TCII- $B_{12}$. This value fell significantly and progressively to $10 \%$ as the amount of unlabeled human TCII- $\mathrm{B}_{12}$ was increased over the range from 2 to $60 \mathrm{ng}$ of protein. Additional details, including the observation that immunoreactive TCII is absent from the plasma of two patients with congenital TCII deficiency, will be presented elsewhere. ${ }^{3}$

Other methods. Gel filtration on Sephadex G-150 (24), $B_{12}$-binding assays (24), $B_{12}$ assays (6), sodium dodecyl sulfate polyacrylamide gel electrophoresis (24), immunization of animals (8), immunodiffusion (8), immunoprecipitation assays (9), and the preparation of $B_{12}$-Sepharose (25) were performed as described previously.

\section{RESULTS}

Gel filtration profile of pooled rabbit serum. When pooled rabbit serum was subjected to gel filtration on Sephadex G-150, the endogenous $B_{19}$ and $B_{12}$-binding ability eluted as shown in Fig. 1A. Over $95 \%$ of the $\mathrm{B}_{12}$-binding ability eluted in a single peak with an apparent mol wt of 40,000 and represents rabbit TCII, since more than $90 \%$ of a saturating amount of $\left[{ }^{87} \mathrm{Co}\right]-$ $\mathrm{B}_{1}$ bound to material in this region was precipitated by chicken anti-human TCII serum. Approximately $80 \%$ of the endogenous $B_{12}$ eluted in the position of rabbit TCII, while approximately $20 \%$ eluted with an apparent mol wt of 145,000 . The nature of the latter material has not been determined, although it may represent rabbit $\mathrm{R}$-type protein. The elution profiles obtained for rabbit serum differ from those obtained for human serum, since human serum contains only $2 \%$ as much $\mathrm{B}_{12}$ and $\mathrm{B}_{12}$-binding ability as rabbit serum, and only $10-20 \%$ of the total $B_{19}$ is bound to human TCII (6, 11).

Properties of ${ }^{185} I$ and ${ }^{181} I$-labeled proteins. When ${ }^{120} \mathrm{I}-$ labeled rabbit TCII was saturated with $\left[{ }^{57} \mathrm{Co}\right] \mathrm{B}_{12}$ and applied to a column of Sephadex G-150, the elution profiles presented in Fig. 1B were obtained. More than $90 \%$ of the $\left[{ }^{57} \mathrm{Co}\right] \mathrm{B}_{12}$ eluted in a symmetrical peak with an apparent mol wt of 40,000 . The majority of the ${ }^{12} \mathrm{I}$ was present in the same region, although a significant amount was spread out from the void volume of the column to the 40,000 apparent mol wt region. The nature of the dispersed ${ }^{125}$ I-labeled material has not been determined, although it may result from alteration of the protein during the ${ }^{125} \mathrm{I}$-labeling procedure or during the guanidine denaturation and renaturation procedure.

${ }^{3}$ Mehlman, C. S., C. R. Scott, and R. H. Allen. Manuscript in preparation. 


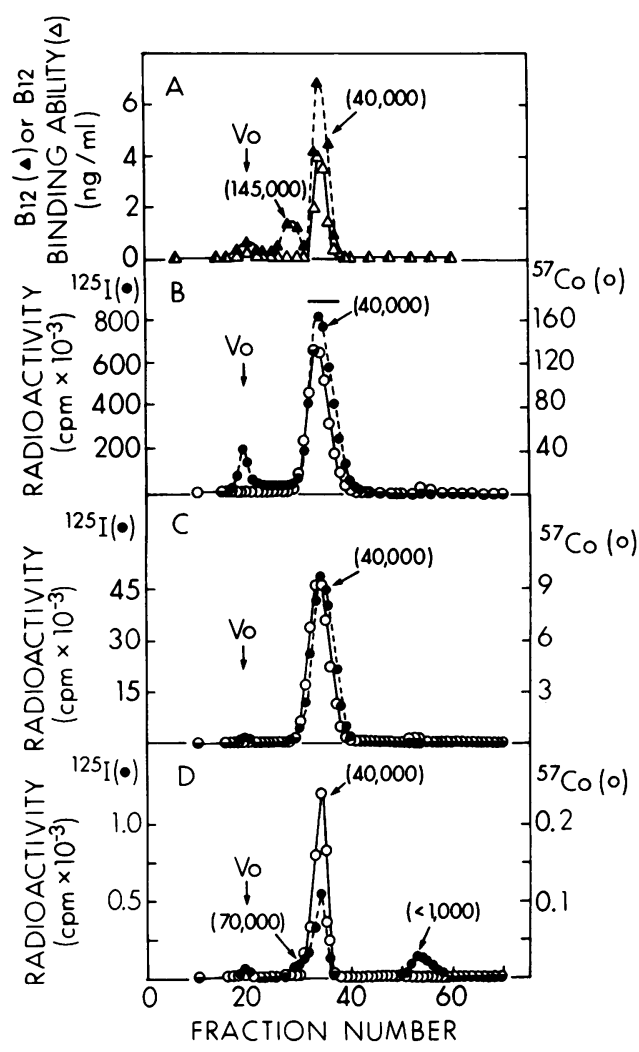

FIgURE $1 \mathrm{Gel}$ filtration of rabbit serum and ${ }^{125} \mathrm{I}$-labeled rabbit TCII- $\left[{ }^{57} \mathrm{Co}\right] \mathrm{B}_{12}$. Samples of $6 \mathrm{ml}$, containing $2 \mathrm{mg}$ of blue dextran, were applied to a column ( $55 \mathrm{~cm}$ in height by $2.0 \mathrm{~cm}$ in diameter) of Sephadex G-150 equilibrated at

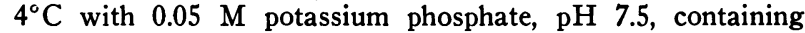
$0.75 \mathrm{M} \mathrm{NaCl}$. Fractions of $3.0 \mathrm{ml}$ were collected in tubes containing $300 \mu \mathrm{g}$ of bovine serum albumin in $150 \mu \mathrm{l}$ of equilibration solution. The void volume of the column at fraction 21 was as indicated by the arrows. The numbers in parentheses indicate apparent molecular weight values, estimated from the elution positions of proteins of known molecular weight. The samples contained: (A) $5.8 \mathrm{ml}$ of pooled rabbit serum containing a total of $174 \mathrm{ng}$ of endogenous $\mathrm{B}_{12}$ and $80 \mathrm{ng}$ of $\mathrm{B}_{12}$-binding ability. (B) Initial preparation of ${ }^{125} \mathrm{I}$-labeled rabbit TCII- $\left[{ }^{57} \mathrm{Co}\right] \mathrm{B}_{12}$ containing $120 \mathrm{ng}$ of $\left[{ }^{57} \mathrm{Co}\right] \mathrm{B}_{12}$ and prepared as described under Methods. The horizontal bar indicates the positions of fractions 32-36, which were pooled. (C) $2.0 \mathrm{ml}$ of pooled fractions 32-36 from B. (D) Rabbit plasma $(6.0 \mathrm{ml})$ obtained from a nephrectomized rabbit $240 \mathrm{~min}$ after the intravenous injection of $2.0 \mathrm{ml}$ of pooled fractions $32-36$ from B. Values from $C$ and $D$ were corrected for isotope decay and variation in counting efficiency, and correspond to the values in B.

This same phenomenon was observed with ${ }^{125} \mathrm{I}$-labeled human TCII- $\left[{ }^{87} \mathrm{Co}\right] \mathrm{B}_{12}$ and with ${ }^{131} \mathrm{I}$-labeled rabbit and human TCII devoid of $\mathrm{B}_{12}$ (data not presented).

The ${ }^{125} \mathrm{I}$-labeled rabbit TCII- $\left[{ }^{57} \mathrm{Co}\right] \mathrm{B}_{12}$ in pooled fractions 32-36 from Fig. 1B was utilized for in vivo experiments. Corresponding pooled fractions were utilized for the other protein preparations. Fig. 1C portrays the elution profiles obtained when an aliquot of the final preparation of ${ }^{125} \mathrm{I}$-labeled rabbit TCII- $\left[{ }^{57} \mathrm{Co}\right] \mathrm{B}_{12}$ was subjected to repeat gel filtration on Sephadex G-150. Approximately $2 \%$ of the ${ }^{125} \mathrm{I}$ was still present in the void volume, and a corresponding amount of $\left[{ }^{87} \mathrm{Co}\right] \mathrm{B}_{19}$ was present as free $\left[{ }^{67} \mathrm{Co}\right] \mathrm{B}_{12}$. Both of these components increase slowly during the storage of ${ }^{125} \mathrm{I}$-labeled rabbit TCII- $\left[{ }^{57} \mathrm{Co}\right] \mathrm{B}_{19}$ at a rate of approximately $2 \%$ of the total per week. The ${ }^{125} \mathrm{I}$ in the void volume was not precipitated by chicken anti-human TCII serum. This phenomenon was observed with the other protein preparations utilized for in vivo experiments. All of the experiments presented here were performed within 3 wk of the labeling of these proteins.

More than $90 \%$ of both moieties of the final preparation of ${ }^{120} \mathrm{I}$-labeled rabbit TCII- $\left[{ }^{57} \mathrm{Co}\right] \mathrm{B}_{12}$ were precipitated by chicken anti-human TCII serum. Less than $10 \%$ of either moiety was precipitated by rabbit antihuman TCII serum, or was absorbed by $\mathrm{B}_{12}$-Sepharose. ${ }^{125}$ I-labeled human TCII- $\left[{ }^{57} \mathrm{Co}\right] \mathrm{B}_{12}$ behaved in the same manner except that more than $90 \%$ of both moieties were precipitated by rabbit anti-human TCII serum. The final preparations of ${ }^{191} \mathrm{I}$-labeled rabbit and human TCII devoid of $B_{12}$ had the same precipitation characteristics as their ${ }^{126} \mathrm{I}$-labeled TCII- $\left[{ }^{\mathrm{s7}} \mathrm{Co}\right] \mathrm{B}_{12}$ counterparts, but the ${ }^{181} \mathrm{I}$-labeled TCII preparations were adsorbed $(>90 \%)$ by $\mathrm{B}_{12}$-Sepharose. The molar ratios of ${ }^{125} \mathrm{I}$ to $\mathrm{B}_{12}$ were 0.2 and 0.3 for the final preparations of ${ }^{125} \mathrm{I}$ labeled rabbit TCII- $\left[{ }^{57} \mathrm{Co}\right] \mathrm{B}_{19}$ and ${ }^{125} \mathrm{I}$-labeled human TCII- $\left[{ }^{57} \mathrm{Co}\right] \mathrm{B}_{12}$, respectively. The same values hold for the molar ratios of ${ }^{125} \mathrm{I}$ to protein, since TCII contains a single $\mathrm{B}_{12}$-binding site (5). The molar ratios of ${ }^{181} \mathrm{I}$ to rabbit and human TCII devoid of $B_{12}$ were not significantly different from those observed with their ${ }^{125} \mathrm{I}$-labeled TCII counterparts based on $\mathrm{B}_{12}$ binding assays performed with the ${ }^{181}$ I-labeled preparations.

Plasma survival of ${ }^{125}$ I-labeled rabbit $T C I I-\left[{ }^{57} \mathrm{Co}\right] B_{18}$. When ${ }^{125} \mathrm{I}$-labeled rabbit TCII- $\left[{ }^{57} \mathrm{Co}\right] \mathrm{B}_{12}$ and ${ }^{181} \mathrm{I}$-labeled bovine serum albumin were simultaneously injected intravenously into a rabbit, the three isotopes were cleared from the plasma and excreted in the urine as shown in Fig. 2. The ${ }^{181} \mathrm{I}$ disappeared slowly from the plasma at a rate compatible with the equilibration of albumin with the extracellular fluid; $65 \%$ of the total amount of ${ }^{181} \mathrm{I}$ administered was present in the plasma $240 \mathrm{~min}$ after the injection. Approximately $5 \%$ of the ${ }^{181} \mathrm{I}$ was excreted in the urine during this time. Similar results were obtained with similarly labeled human transferrin in other experiments (data not presented). During the first $60 \mathrm{~min}$ after the injection, ${ }^{\circ} \mathrm{Co}$ and ${ }^{125} \mathrm{I}$ disappeared from the plasma at identical rates faster than that of ${ }^{181} \mathrm{I}$. From 60 to 240 min, the plasma disappearance rate of ${ }^{57} \mathrm{Co}$ decreased, and $25 \%$ of the ${ }^{57} \mathrm{Co}$ remained in the plasma at the end of 
this time. Less than $1 \%$ of the ${ }^{87}$ Co was excreted in the urine during the $240 \mathrm{~min}$ period. After $60 \mathrm{~min}$, the ${ }^{195} \mathrm{I}$ continued its initial rapid disappearance from the plasma, and only $15 \%$ remained after $240 \mathrm{~min}$. After a delay of $30 \mathrm{~min}$, large amounts of ${ }^{125} \mathrm{I}$ appeared in the urine; $42 \%$ of the administered amount had been excreted at the end of $240 \mathrm{~min}$. The peak period of urinary excretion occurred at 60-100 min.

From the assumption that the difference between the plasma survival of ${ }^{125} \mathrm{I}$ and ${ }^{120} \mathrm{I}$ represents the tissue uptake of ${ }^{125} \mathrm{I}$ that is not attributable to diffusion into the extracellular fluid, a $t_{1}$ of approximately $90 \mathrm{~min}$ was estimated for this process. This value also holds for ${ }^{67} \mathrm{Co}$ during the initial $60 \mathrm{~min}$ after the injection of ${ }^{120} \mathrm{I}$-labeled rabbit TCII- $\left[{ }^{57} \mathrm{Co}\right] \mathrm{B}_{12}$.

Properties of ${ }^{185} I$ in the urine, and ${ }^{105} I$ and ${ }^{57} \mathrm{Co}$ in the plasma after the intravenous injection of ${ }^{195} I$-labeled rabbit $T C I I-\left[{ }^{57} \mathrm{Co}\right] B_{18}$. When a sample of pooled urine obtained from the experiment shown in Fig. 2 was subjected to gel filtration on Sephadex G-150, all of the ${ }^{195} \mathrm{I}$ eluted in a single peak with an apparent mol wt of less than 1,000 (data not presented), suggesting that a significant portion of the ${ }^{125}$ I-labeled rabbit TCII had been degraded during the experiment. Although the kidney is responsible for its excretion, at least a major part of this low-molecular-weight material must be formed by other tissues, since it was present in significant amounts in a 240-min plasma sample obtained from a rabbit nephrectomized $1 \mathrm{~h}$ before the injection of ${ }^{125} \mathrm{I}$-labeled rabbit TCII- $\left[{ }^{87} \mathrm{Co}\right] \mathrm{B}_{12}$. The elution profile of this plasma sample is presented in Fig. $1 \mathrm{D}$ and reveals that essentially $100 \%$ of the ${ }^{57} \mathrm{Co}$, but only $50 \%$ of the ${ }^{125} \mathrm{I}$, eluted with an apparent mol wt of 40,000 , the same as that of the starting material (seen Fig. 1C). More than $90 \%$ of the ${ }^{125} \mathrm{I}$ and ${ }^{57} \mathrm{Co}$ in this position were precipitated by chicken anti-human TCII serum; less than $10 \%$ were

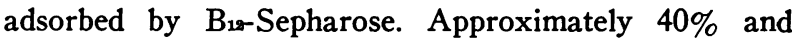
$10 \%$ of the plasma ${ }^{125} \mathrm{I}$ eluted with apparent mol wts of less than 1,000, and 70,000, respectively. None of the ${ }^{125} \mathrm{I}$ in either position was precipitated by chicken antihuman TCII serum or adsorbed by $\mathrm{B}_{12}$-Sepharose. The nature of the ${ }^{120} \mathrm{I}$ in the less than $1,000 \mathrm{~mol}$ wt region has not been determined, although free ${ }^{125} \mathrm{I}$ and ${ }^{125} \mathrm{I}$-labeled $N$-succinimidyl-3-(4-hydroxyphenyl) propionate, either free or attached to one or a few amino acids, are likely possibilities. The nature of the ${ }^{195} \mathrm{I}$ in the 70,000mol-wt region is also unknown, although the ${ }^{120} \mathrm{I}$ appears to be covalently bound to some component, possibly rabbit albumin, since it was not dialysable when the plasma was dialyzed against $1 \%$ sodium dodecyl sulfate or $7.5 \mathrm{M}$ guanidine- $\mathrm{HCl}$ containing $1 \% 2$-mercaptoethanol. The fact that similar material has been observed (13) after the intravenous injections of ${ }^{120} \mathrm{I}-\mathrm{la}-$ beled human granulocyte $\mathrm{B}_{12}$-binding protein and trans-

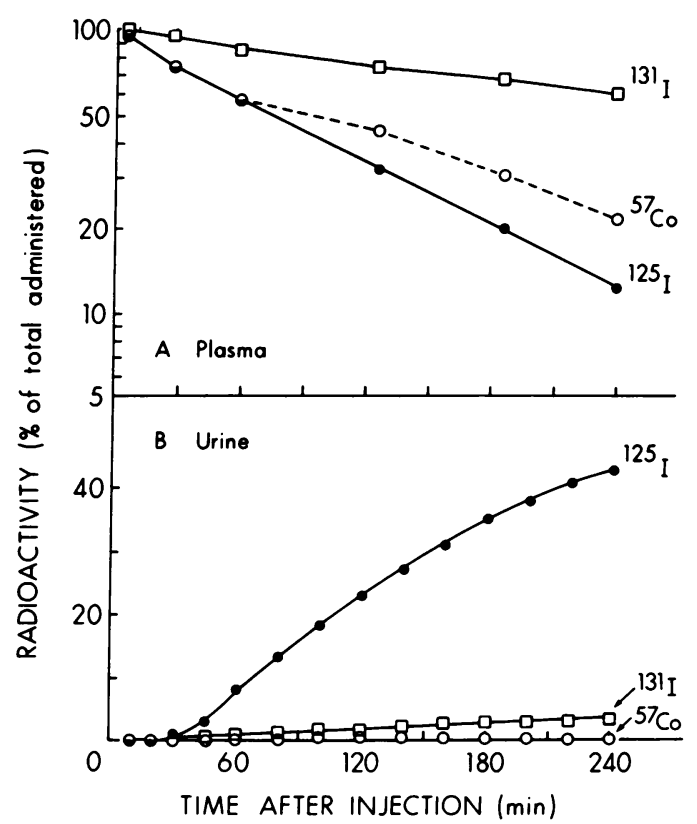

FIGURE 2 Plasma survival and urinary excretion of ${ }^{125} \mathrm{I}$, ${ }^{57} \mathrm{Co}$, and ${ }^{131} \mathrm{I}$ after the simultaneous intravenous injection of ${ }^{125} \mathrm{I}$-labeled rabbit $\mathrm{TCII}-\left[{ }^{67} \mathrm{Co}\right] \mathrm{B}_{12}$ and ${ }^{131} \mathrm{I}$-labeled bovine serum albumin into a rabbit. The amount of each labeled protein injected was approximately $150 \mathrm{ng}$. The amount of $B_{12}$ injected was approximately $5 \mathrm{ng}$. The amount of ${ }^{181} \mathrm{I}$ present in the plasma $5 \mathrm{~min}$ after injection was assumed to be $100 \%$ of the injected amount and was used to calculate the plasma volume, assumed to remain constant throughout the experiment. A, plasma; B, cumulative urinary excretion.

cobalamin III suggests that it is formed after the catabolism of a number of similarly iodinated proteins.

Plasma samples obtained 5, 30,60,120,180, 240, and $1,440 \mathrm{~min}$ after the simultaneous intravenous injection of ${ }^{120} \mathrm{I}$-labeled rabbit TCII- $\left[{ }^{87} \mathrm{Co}\right] \mathrm{B}_{12}$ and ${ }^{191} \mathrm{I}$-labeled bovine serum albumin into unnephrectomized rabbits were also studied by gel filtration. These studies revealed that the ratio of ${ }^{125} \mathrm{I}$ to ${ }^{87} \mathrm{Co}$ in the 40,000 apparent mol wt region was equal to the preinjection ratio in the 5 - and 30 -min samples and declined progressively in the 60 - to 1,440 -min. samples. All of the ${ }^{57} \mathrm{Co}$ in each sample was located in the apparent 40,000-mol-wt region. The lowmol-wt ${ }^{125} \mathrm{I}$-material was not detectable in the 5- and 30 -min plasma samples. It was present in greatest absolute and relative ( $10 \%$ of plasma $\left.{ }^{125} \mathrm{I}\right)$ amount in the 60-min sample, and declined thereafter. The ${ }^{125} \mathrm{I}$ with an apparent mol wt of 70,000 was first detected in the 60min sample, where it accounted for $1 \%$ of the total ${ }^{125} \mathrm{I}$; it slowly increased subsequently and accounted for $5 \%$ of the total ${ }^{125} \mathrm{I}$ in the 240 -min sample. More than $90 \%$ of the ${ }^{181} \mathrm{I}$ in these samples eluted with an apparent mol wt of 70,000, the same as that of the ${ }^{121}$ I-labeled bovine serum albumin in the starting sample. 


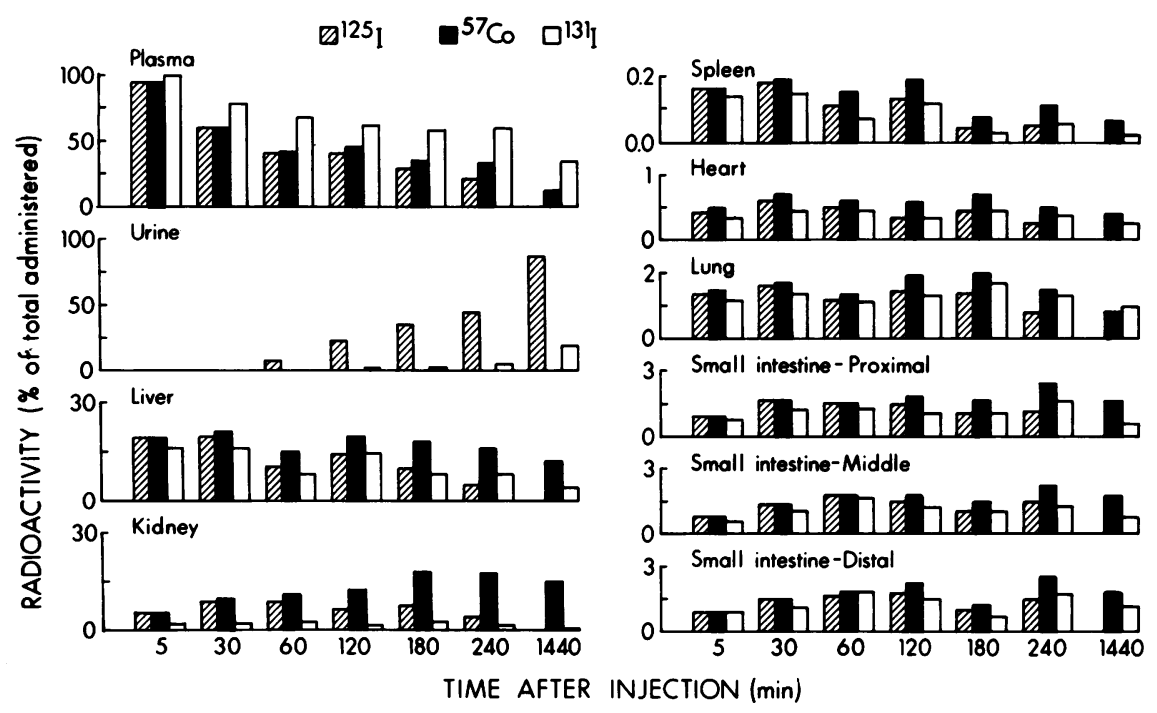

FIgure 3 Tissue distribution of ${ }^{125} \mathrm{I},{ }^{67} \mathrm{Co}$, and ${ }^{131} \mathrm{I}$ at various time periods after the simultaneous injection of ${ }^{128} \mathrm{I}$-labeled rabbit TCII- $\left[{ }^{57} \mathrm{Co}\right] \mathrm{B}_{12}$ and ${ }^{181} \mathrm{I}$-labeled bovine serum albumin into rabbits. Experiments and calculations were performed as described in the legend to Fig. 2. The values for the 5- and 30-min time periods are average values obtained from five animals. The values for the other time periods were obtained from single animals. The entire small intestine, including its contents, was divided into three segments of equal length.

Tissue, rather than plasma or blood cells alone, appears to be required for the formation of the low-mol-wt ${ }^{205}$ I-material, since when 5 -min plasma and whole blood samples were incubated in vitro for $240 \mathrm{~min}$ at $37^{\circ} \mathrm{C}$, with subsequent application of the plasmas to columns of Sephadex G-150, more than $95 \%$ of the ${ }^{125} \mathrm{I}$ and $\left[{ }^{87} \mathrm{Co}\right]-$ Ba eluted in the 40,000-mol-wt position. Only approximately $10 \%$ of the ${ }^{10} \mathrm{I}$ was adsorbed by $\mathrm{B}_{12}$-Sepharose, thus indicating that significant dissociation of the complex had not occurred.

Tissue distribution of ${ }^{125} \mathrm{I}$-labeled rabbit $\mathrm{TCII}-\left[{ }^{67} \mathrm{Co}\right]$ $B_{13}$. The tissue distributions of ${ }^{185} \mathrm{I},{ }^{87} \mathrm{Co}$, and ${ }^{201} \mathrm{I}$ were determined at various times from 5 to $1,440 \mathrm{~min}$ after the simultaneous intravenous injection of I-labeled rabbit TCII- $\left[{ }^{57} \mathrm{Co}\right] \mathrm{B}_{1 s}$ and ${ }^{121} \mathrm{I}$-labeled bovine serum albumin into rabbits. The results are presented in Fig. 3

TABLE I

Relative Tissue Distribution of ${ }^{125} I,{ }^{131} I$, and ${ }^{57} \mathrm{Co}, 30$ min after the Simultaneous Intravenous Injection of ${ }^{125}$ I-Labeled Rabbit TCII-[ $\left.{ }^{57} \mathrm{Co}\right] B_{12}$ and ${ }^{131} I$-Labeled Bovine Serum Albumin into Rabbits

\begin{tabular}{|c|c|c|c|c|c|c|}
\hline \multirow[b]{2}{*}{ Organ } & \multicolumn{2}{|c|}{ 126I / $/ 121 I$} & \multicolumn{2}{|c|}{${ }^{67} \mathrm{Co} / 1281 \mathrm{I}$} & \multicolumn{2}{|c|}{${ }^{125} \mathrm{I} / \mathrm{s}^{57} \mathrm{Co}$} \\
\hline & Range & Mean & Range & Mean & Range & Mean \\
\hline Plasma & $0.70-0.80$ & $0.76^{*}$ & $0.75-0.80$ & $0.78^{*}$ & $0.94-1.02$ & 0.98 \\
\hline Liver & $1.10-1.49$ & $1.29^{*}$ & $1.14-1.70$ & $1.38^{*}$ & $0.90-1.00$ & 0.95 \\
\hline Kidney & $2.85-4.51$ & $3.60^{*}$ & $2.97-4.57$ & $3.58^{*}$ & $0.92-1.09$ & 1.00 \\
\hline Spleen & $1.15-1.65$ & $1.37 \ddagger$ & $1.11-1.80$ & $1.44 \ddagger$ & $0.88-1.11$ & 0.98 \\
\hline Heart & $1.17-1.46$ & $1.31^{*}$ & $1.41-1.75$ & $1.59^{*}$ & $0.77-0.88$ & $0.83^{*}$ \\
\hline Lung & $1.04-1.31$ & $1.14 \ddagger$ & $1.17-1.45$ & $1.26^{*}$ & $0.88-0.93$ & $0.90^{*}$ \\
\hline \multicolumn{7}{|c|}{ Small intestine } \\
\hline Proximal & $1.08-1.49$ & $1.21 \ddagger$ & $1.09-1.35$ & $1.26^{*}$ & $0.98-1.12$ & 1.04 \\
\hline Middle & $1.23-1.30$ & $1.27^{*}$ & $1.18-1.39$ & $1.29^{*}$ & $0.91-1.05$ & 0.98 \\
\hline Distal & $1.16-1.37$ & $1.24^{*}$ & $1.06-1.40$ & $1.30^{*}$ & $0.86-1.10$ & 0.96 \\
\hline
\end{tabular}

Five rabbits were injected. Statistical analysis employed the Student $t$ test and was based on the assumption that $\log { }^{125} \mathrm{I} /{ }^{131} \mathrm{I}$, etc. were normally distributed. The ratios were calculated on the basis of the percentage of the total amount of each isotope administered.

* The value differs from 1.00 at $P<0.01$.

$\ddagger$ The value differs from 1.00 at $P<0.05$. 
and reveal that the tissue distributions of ${ }^{125} \mathrm{I}$ and ${ }^{57} \mathrm{Co}$ were similar to each other $30 \mathrm{~min}$ after injection and that both isotopes were present in excess of ${ }^{101} \mathrm{I}$ at this time in all of the tissues studied. The significance of these results was confirmed by the statistical analysis (see Table I) of data obtained from five rabbits sacrificed 30 min after injection. Small but significant differences between the contents of ${ }^{195} \mathrm{I}$ and ${ }^{57} \mathrm{Co}$ were observed in the heart and lung. These differences could be due either to early release of ${ }^{125} \mathrm{I}$ from these organs or to insufficient adjustment for the decrease in counting efficiency for ${ }^{120} \mathrm{I}$ in these organs, since ${ }^{120} \mathrm{I}$-labeled rabbit TCII might not have the same intraorgan distribution as the ${ }^{105} \mathrm{I}$ labeled bovine serum albumin upon which the adjustments were based, as described under Methods. The net tissue uptake of ${ }^{125} \mathrm{I}$ and ${ }^{87} \mathrm{Co}$ at $30 \mathrm{~min}$ was actually somewhat greater than that shown in Fig. 3 and Table I, since all of the tissues were contaminated by plasma containing ${ }^{10 \mathrm{I}} \mathrm{I}$, present in approximately $20 \%$ excess of ${ }^{125} \mathrm{I}$ and ${ }^{57} \mathrm{Co}$.

From 60 to $1,440 \mathrm{~min}$ after injection, the ratio of ${ }^{57} \mathrm{Co}$ to ${ }^{181} \mathrm{I}$ remained high in all of the tissues (see Fig. 3 ), but the ratios of ${ }^{125} \mathrm{I}$ to ${ }^{181} \mathrm{I}$ and ${ }^{125} \mathrm{I}$ to ${ }^{57} \mathrm{Co}$ decreased progressively and reached values of less than 0.1 by $1,440 \mathrm{~min}$. The data in Fig. 3 also reveal that individual tissues varied markedly in their contents of ${ }^{57} \mathrm{Co}$. When the amount of ${ }^{57} \mathrm{Co}$ present in the tissues at $1,440 \mathrm{~min}$ was corrected for the amount present in contaminating plasma and extracellular fluid (based on the ${ }^{191} \mathrm{I}$ content of individual tissues and the ratio of ${ }^{57} \mathrm{Co}$ to ${ }^{181} \mathrm{I}$ in plasma), the following values for the tissue contents of ${ }^{57} \mathrm{Co}$, expressed as percent of administered ${ }^{57} \mathrm{Co}$ per gram of tissue, wet wt, were obtained: kidney, 1.29; liver, 0.192 ; spleen, 0.074 ; heart, 0.071 ; lung, 0.050 ; proximal small intestine, 0.079 ; middle small intestine, 0.076 ; and distal small intestine, 0.063 . Values of 0.010 and less than $<0.005$ were obtained for skeletal muscle and femoral bone marrow, respectively.

The high kidney content of ${ }^{57} \mathrm{Co}$ was not reduced when rabbits were subjected to bilateral ureteral ligation 60 min before the injection of rabbit TCII- $\left[{ }^{57} \mathrm{Co}\right] \mathrm{B}_{12}$. This observation suggests that glomerular filtration of TCII$B_{19}$ is not involved in the process by which the kidney takes up TCII-B口2.

Additional experiments were performed in which ${ }^{125} \mathrm{I}-$ labeled rabbit TCII- $\left[{ }^{57} \mathrm{Co}\right] \mathrm{B}_{19}$ and $\left[{ }^{58} \mathrm{Co}\right] \mathrm{B}_{12}$ bound to unpurified TCII present in pooled rabbit serum were injected simultaneously into rabbits. The plasma and individual tissue contents of ${ }^{57} \mathrm{Co}$ and ${ }^{88} \mathrm{Co}$ differed from each other by less than $5 \%$ at 1,4 , and $24 \mathrm{~h}$ after injection. Several experiments were performed in which pentobarbital was omitted. The results obtained were indistinguishable from those in pentobarbital-treated rabbits.

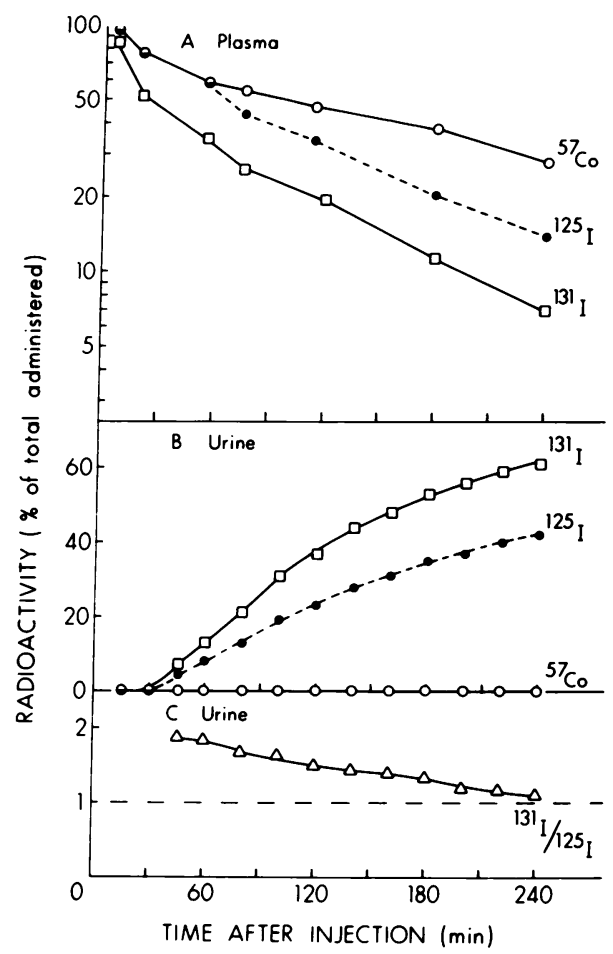

FIGURE 4 Plasma survival and cumulative urinary excretion of ${ }^{125} \mathrm{I},{ }^{57} \mathrm{Co}$, and ${ }^{181} \mathrm{I}$, and the ratio of ${ }^{181} \mathrm{I}$ to ${ }^{105} \mathrm{I}$ in individual urine samples after the simultaneous intravenous injection of ${ }^{120} \mathrm{I}$-labeled rabbit TCII- $\left[{ }^{57} \mathrm{Co}\right] \mathrm{B}_{19}$ and ${ }^{191} \mathrm{I}-$ labeled rabbit TCII devoid of $B_{12}$ into a rabbit. The experiment was performed as described in the legend to Fig. 2 , except that the plasma volume was calculated with the assumption that $95.2 \%$ of the injected $\left[{ }^{87} \mathrm{Co}\right] \mathrm{B}_{18}$ was present in the plasma $5 \mathrm{~min}$ after its injection. The value of $95.2 \%$ is the average value obtained for ${ }^{57} \mathrm{Co}$ in 16 experiments in which ${ }^{125} \mathrm{I}$-labeled rabbit TCII- $\left[{ }^{87} \mathrm{Co}\right] \mathrm{B}_{12}$ was injected simultaneously with ${ }^{181} \mathrm{I}$-labeled bovine serum albumin.

Plasma survival and tissue distribution of apo- and holo-rabbit TCII. When ${ }^{181} \mathrm{I}$-labeled rabbit TCII devoid of $\mathrm{B}_{18}$ was mixed with ${ }^{125} \mathrm{I}$-labeled rabbit TCII$\left[{ }^{57} \mathrm{Co}^{\mathrm{B}} \mathrm{B}_{1 \mathrm{~s}}\right.$ and injected intravenously into a rabbit, the ${ }^{181} \mathrm{I}$ disappeared from the plasma $30 \%$ faster than the ${ }^{125} \mathrm{I}$, and more ${ }^{131} \mathrm{I}$ than ${ }^{120} \mathrm{I}$ was excreted in the urine during the 240-min course of the experiment, as shown in Fig. 4. When the ${ }^{121}$ I-labeled rabbit TCII was saturated with unradioactive $B_{12}$ before this experiment was repeated, the plasma survivals and urinary excretions of ${ }^{125} \mathrm{I}$ and ${ }^{180} \mathrm{I}$ were no longer distinguishable from each other (data not presented). All of the urinary ${ }^{120} \mathrm{I}$ and ${ }^{100} \mathrm{I}$ in these experiments had an apparent mol wt of less than 1,000 based on gel filtration.

Data concerning the tissue distributions of ${ }^{121} \mathrm{I},{ }^{125} \mathrm{I}$, and ${ }^{87} \mathrm{Co} 30 \mathrm{~min}$ after the simultaneous intravenous injection of ${ }^{281} \mathrm{I}$-labeled rabbit TCII and ${ }^{125} \mathrm{I}$-labeled rabbit TCII$\left[{ }^{57} \mathrm{Co}\right] \mathrm{B}_{1}$ are presented in Table II. The failure to find marked differences in the ratio of ${ }^{125} \mathrm{I}$ to ${ }^{180} \mathrm{I}$ in the tis- 
TABLE II

Relative Tissue Distribution of ${ }^{125} \mathrm{I},{ }^{131} \mathrm{I}$, and ${ }^{57} \mathrm{Co}, 30$ min after the Simultaneous Intravenous Injection of ${ }^{125}$ I-Labeled Rabbit TCII-[ $\left[{ }^{57} \mathrm{Co}\right] B_{12}$ and ${ }^{131}$ I-Labeled Rabbit TCII into Rabbits

\begin{tabular}{|c|c|c|c|c|c|c|}
\hline \multirow[b]{2}{*}{ Organ } & \multicolumn{2}{|c|}{${ }^{125} \mathrm{I} / \mathbf{1 2 1} \mathrm{I}$} & \multicolumn{2}{|c|}{${ }^{57} \mathrm{Co} / 1211$} & \multicolumn{2}{|c|}{${ }^{125} \mathrm{I} /{ }^{57} \mathrm{Co}$} \\
\hline & Range & Mean & Range & Mean & Range & Mean \\
\hline Plasma & $1.07-1.15$ & $1.13^{*}$ & $1.05-1.20$ & $1.14^{*}$ & $0.96-1.02$ & 0.99 \\
\hline Liver & $0.92-1.09$ & 0.99 & $0.94-1.13$ & 1.07 & $0.89-1.00$ & 0.94 \\
\hline Kidney & $0.80-0.91$ & $0.84^{*}$ & $0.75-0.96$ & $0.81^{*}$ & $0.95-1.07$ & 1.03 \\
\hline Spleen & $0.85-1.23$ & 1.02 & $0.86-1.29$ & 1.04 & $0.96-1.01$ & 0.98 \\
\hline Heart & $1.13-1.22$ & $1.17^{*}$ & $1.31-1.43$ & $1.39^{*}$ & $0.83-0.86$ & $0.84^{*}$ \\
\hline Lung & $1.09-1.17$ & $1.12^{*}$ & $1.10-1.30$ & $1.20^{*}$ & $0.90-0.99$ & $0.94 \ddagger$ \\
\hline \multicolumn{7}{|c|}{ Small intestine } \\
\hline Proximal & $0.91-1.05$ & 1.01 & $0.92-1.02$ & 0.97 & $0.98-1.09$ & 1.04 \\
\hline Middle & $0.98-1.08$ & 1.04 & $1.01-1.32$ & 1.11 & $0.81-1.01$ & 0.94 \\
\hline Distal & $0.98-1.15$ & 1.05 & $1.03-1.24$ & $1.11 \ddagger$ & $0.86-1.10$ & 0.96 \\
\hline
\end{tabular}

Five rabbits were injected. Statistical analysis employed the Student $t$ test and was based on the assumption that $\log { }^{126} \mathrm{I} /{ }^{131} \mathrm{I}$, etc. were normally distributed. The ratios were calculated on the basis of the percent of the total amount of each isotope administered.

* The value differs from 1.00 at $P<0.01$.

$\ddagger$ The value differs from 1.00 at $P<0.05$.

sues examined indicates that apo- and holo-rabbit TCII are taken up by tissues similarly, although not identically.

The experiments in this section suggested that the ${ }^{125} \mathrm{I}$ moiety of ${ }^{125}$ I-labeled rabbit TCII- $\left[{ }^{57} \mathrm{Co}\right] \mathrm{B}_{18}$ might be converted to its low-mol-wt form only after the release of $\left[{ }^{57} \mathrm{Co}\right] \mathrm{B}_{12}$ to tissues, and only if the ${ }^{125} \mathrm{I}$-labeled rabbit TCII fails to bind another molecule of $B_{12}$ in the plasma. This possibility was tested by injecting $5 \mathrm{mg}$ of $B_{12}$ intravenously immediately before the injection of ${ }^{125} \mathrm{I}-\mathrm{la}$ beled rabbit TCII- $\left[{ }^{87} \mathrm{Co}\right] \mathrm{B}_{12}$, and subsequently maintaining a continuous infusion of unradioactive $\mathrm{B}_{12}$ at a rate of $5 \mathrm{\mu g} / \mathrm{min}$. This possibility appears unlikely, since under these conditions of continuous saturation of TCII with $B_{12}$, the ${ }^{125} \mathrm{I}$ was cleared rapidly from the plasma at its usual rate and $45 \%$ of the ${ }^{125} \mathrm{I}$ was excreted in the urine during the 240-min course of the experiment.

Comparison of rabbit TCII and human TCII. When ${ }^{125} \mathrm{I}$-labeled human TCII- $\left[{ }^{57} \mathrm{Co}\right] \mathrm{B}_{18}$ was mixed with ${ }^{181} \mathrm{I}$ labeled rabbit TCII- $\mathrm{B}_{12}$ and injected intravenously into a rabbit, the ${ }^{125} \mathrm{I}$ was cleared from the plasma and excreted in the urine faster than the ${ }^{181} \mathrm{I}$, as shown in Fig. 5. When ${ }^{125} \mathrm{I}$-labeled human TCII- $\left[{ }^{57} \mathrm{Co}\right] \mathrm{B}_{12}$ was mixed with native rabbit $\mathrm{TCII}-\left[{ }^{58} \mathrm{CO}\right] \mathrm{B}_{12}$ and injected intravenously into a rabbit, ${ }^{57} \mathrm{Co}$ was cleared from the plasma faster than ${ }^{88} \mathrm{Co}$, as shown in Fig. 6. The rabbit utilized for this experiment was sacrificed $240 \mathrm{~min}$ after the injection, and the tissue distributions of ${ }^{57} \mathrm{Co}$ and ${ }^{88} \mathrm{Co}$ were determined. The data are presented in Table III and reveal marked differences in the ratio of ${ }^{57} \mathrm{Co}$ to ${ }^{58} \mathrm{Co}$ in individual tissues. This observation suggests that individual tissues may vary in the degree with which they take up $B_{1}$ bound to human and rabbit TCII. No firm conclusions can be reached in this regard, however, since some or all of the differences in the ratio of ${ }^{57} \mathrm{Co}$ to ${ }^{68} \mathrm{Co}$ could be due to differences in the recirculation of ${ }^{87} \mathrm{Co}$ and ${ }^{58} \mathrm{Co}$ or to differences in tissue contamination with plasma and extracellular fluid.

When $\left[{ }^{57} \mathrm{Co}\right] \mathrm{B}_{1 \mathrm{~s}}$ bound to partially purified human TCII (obtained by incubating $\left[{ }^{57} \mathrm{Co}\right] \mathrm{B}_{12}$ with human serum and isolating TCII- $\left[{ }^{57} \mathrm{Co}\right] \mathrm{B}_{18}$ by gel filtration) was mixed with $\left[{ }^{58} \mathrm{Co}\right] \mathrm{B}_{13}$ bound to similarly partially purified rabbit TCII and injected, the $\left[{ }^{57} \mathrm{Co}\right] \mathrm{B}_{12}$ was also cleared more rapidly than the $\left[{ }^{58} \mathrm{Co}\right] \mathrm{B}_{12}$, thus indicating that the purification and labeling of the TCII molecule was not the cause of the differences observed between human TCII- $\mathrm{B}_{12}$ and rabbit TCII-B12. This view is also supported by experiments that demonstrated (data not presented) that $\left[{ }^{58} \mathrm{Co}\right] \mathrm{B}_{12}$ bound to partially purified human TCII was cleared from rabbit plasma by tissues in a manner indistinguishable from simultaneously injected $\left[{ }^{67} \mathrm{Co}\right] \mathrm{B}_{18}$ bound to ${ }^{120} \mathrm{I}$-labeled human TCII. Tissue distribution data were obtained 1, 4, and $24 \mathrm{~h}$ after injection. When ${ }^{125} \mathrm{I}$-labeled human TCII$\left[{ }^{57} \mathrm{Co}\right] \mathrm{B}_{12}$ was incubated with rabbit plasma for $4 \mathrm{~h}$ at $37^{\circ} \mathrm{C}$, more than $90 \%$ of the ${ }^{125} \mathrm{I}$ and ${ }^{57} \mathrm{Co}$ eluted from Sephadex G-150 with an apparent mol wt of approximately 38,000 and were adsorbed by rabbit anti-human TCII-Sepharose. This indicates that human TCII was not degraded and that $\mathrm{B}_{12}$ bound to human TCII did not exchange markedly with rabbit TCII under these conditions.

Plasma survival of apo- and holo-human TCII. When ${ }^{125} \mathrm{I}$-labeled human TCII- $\left[{ }^{87} \mathrm{Co}\right] \mathrm{B}_{12}$ was mixed with ${ }^{181} \mathrm{I}-$ labeled human TCII and injected intravenously into a 
rabbit, the ${ }^{12} \mathrm{I}$ was cleared from the plasma approximately $30 \%$ faster than the ${ }^{150} \mathrm{I}$, as shown in Fig. 7 . The urinary excretion of ${ }^{181} \mathrm{I}$ also proceeded faster than that of ${ }^{125} \mathrm{I}$. All of the ${ }^{125} \mathrm{I}$ and ${ }^{181} \mathrm{I}$ in the urine had an apparent mol wt of less than 1,000 , based on gel filtration.

Plasma survival of human TCII as determined by radioimmunoassay. Purified but unlabeled human TCII$\mathrm{B}_{19}\left(24 \mu \mathrm{g}\right.$ of protein and $0.74 \mu \mathrm{g}$ of $\left.\mathrm{B}_{12}\right)$ was mixed with ${ }^{121}$ I-labeled bovine serum albumin and injected intravenously into a rabbit. The amount of TCII-Ba injected increased the rabbit's total plasma TCII-B口2 concentration by approximately $15 \%$. The content of human TCII in plasma samples obtained from 5 to 1,440 min after injection was assayed by a radioimmunoassay specific for human TCII, as compared with rabbit TCII, since the antiserum was raised in rabbits. The plasma survival data are presented in Fig. 8 and reveal that the plasma survival of unlabeled human TCII based on the

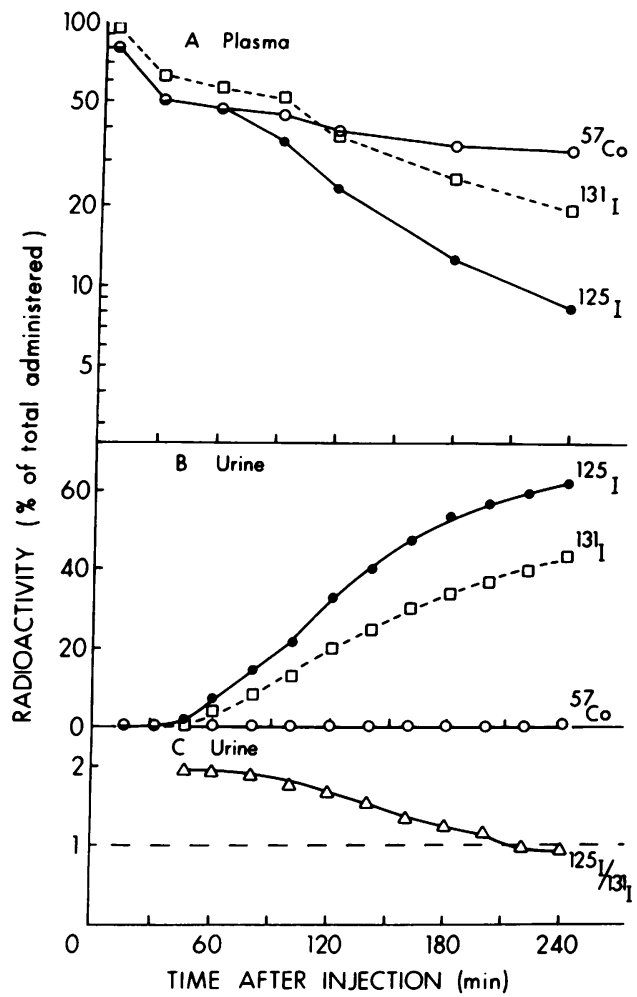

FIGURE 5 Plasma survival and cumulative urinary excretion of ${ }^{120} \mathrm{I},{ }^{87} \mathrm{Co}$, and ${ }^{189} \mathrm{I}$ and the ratio of ${ }^{185} \mathrm{I}$ to ${ }^{181} \mathrm{I}$ in individual urine samples after the simultaneous intravenous injection of ${ }^{185} \mathrm{I}$-labeled human TCII- $\left[{ }^{87} \mathrm{Co}\right] \mathrm{B}_{13}$ and ${ }^{281} \mathrm{I}-$ labeled rabbit TCII-B $\mathrm{B}_{12}$ into a rabbit. The experiment was performed as described in the legend to Fig. 2, except that the plasma volume was calculated on the assumption that $94.7 \%$ of the injected ${ }^{181} \mathrm{I}$ was present in the plasma $5 \mathrm{~min}$ after its injection. The value of $94.7 \%$ is the average value observed for ${ }^{105} \mathrm{I}$ in 16 experiments in which ${ }^{105} \mathrm{I}$-labeled rabbit TCII- $\left[{ }^{87} \mathrm{Co}\right] \mathrm{B}_{12}$ was injected simultaneously with ${ }^{281}$ I-labeled bovine serum albumin.

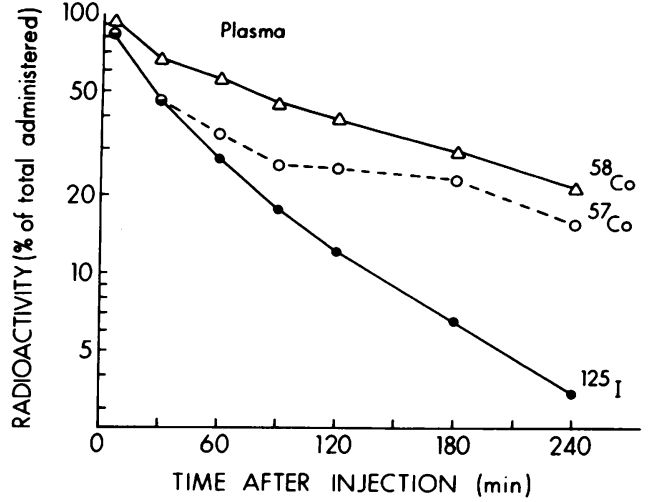

FIGURE 6 Plasma survival of ${ }^{185} \mathrm{I},{ }^{57} \mathrm{Co}$, and ${ }^{58} \mathrm{Co}$ after the simultaneous intravenous injection of ${ }^{125} \mathrm{I}$-labeled human TCII- $\left[{ }^{57} \mathrm{Co}\right] \mathrm{B}_{12}$ and unlabeled rabbit TCII- $\left[{ }^{88} \mathrm{Co}\right] \mathrm{B}_{12}$. The experiment was performed as described in the legends to Figs. 2 and 4 . The injected unlabeled rabbit TCII- $\left[{ }^{\infty} \mathrm{Co}\right] \mathrm{B}_{19}$ (25 $\mathrm{ng} \mathrm{B}_{12}$ ) was prepared by incubating a 1.1-fold excess of $\left[{ }^{88} \mathrm{Co}\right] \mathrm{B}_{12}$ with $5.8 \mathrm{ml}$ of pooled rabbit serum at $4^{\circ} \mathrm{C}$ for $45 \mathrm{~min}$ and subsequently subjecting the sample to gel filtration on Sephadex G-150 as described in the legend to Fig. 1.

radioimmunoassay was essentially the same as that determined with ${ }^{105}$ I-labeled human TCII (compare Fig. 8 with Figs. 5, 6, and 7). The same result was obtained when this experiment was repeated with a second rabbit. These observations are consistent with the concept that TCII is degraded after its uptake by tissues and make it extremely unlikely that the small-mol-wt ${ }^{150} \mathrm{I}-$ material is formed by mere elution of the ${ }^{100} \mathrm{I}$ from the TCII molecule.

\section{DISCUSSION}

The studies presented here demonstrate that rabbit and human TCII can be covalently labeled with ${ }^{100} \mathrm{I}$ - or ${ }^{181} \mathrm{I}$ -

TABLE III

Tissue Distribution of ${ }^{125} \mathrm{I},{ }^{57} \mathrm{Co}$, and ${ }^{58} \mathrm{Co} 240 \mathrm{~min}$ after the Simultaneous Intravenous Injection of ${ }^{125} I$ Labeled Human TCII-[ $\left.{ }^{57} \mathrm{Co}\right] B_{12}$ and Rabbit TCII-[ $\left.{ }^{68} \mathrm{Co}\right] B_{12}$

\begin{tabular}{|c|c|c|c|c|}
\hline Organ & 1281 & ${ }^{57} \mathrm{Co}$ & ${ }^{68} \mathrm{Co}$ & ${ }^{67} \mathrm{Co} / 58 \mathrm{Co}$ \\
\hline & \multicolumn{4}{|c|}{ \% of total administered } \\
\hline Plasma & 3.18 & 15.2 & 20.9 & 0.73 \\
\hline Liver & 1.17 & 15.8 & 11.3 & 1.39 \\
\hline Kidney & 2.12 & 24.1 & 13.4 & 1.80 \\
\hline Spleen & 0.008 & 0.105 & 0.102 & 1.03 \\
\hline Heart & 0.081 & 0.571 & 0.535 & 1.07 \\
\hline Lung & 0.186 & 0.980 & 1.020 & 0.96 \\
\hline \multicolumn{5}{|c|}{ Small intestine } \\
\hline Proximal & 0.186 & 1.32 & 1.48 & 0.90 \\
\hline Middle & 0.217 & 1.21 & 1.27 & 0.95 \\
\hline Distal & 0.377 & 1.54 & 1.58 & 0.97 \\
\hline
\end{tabular}

Values were obtained from a single experiment. 


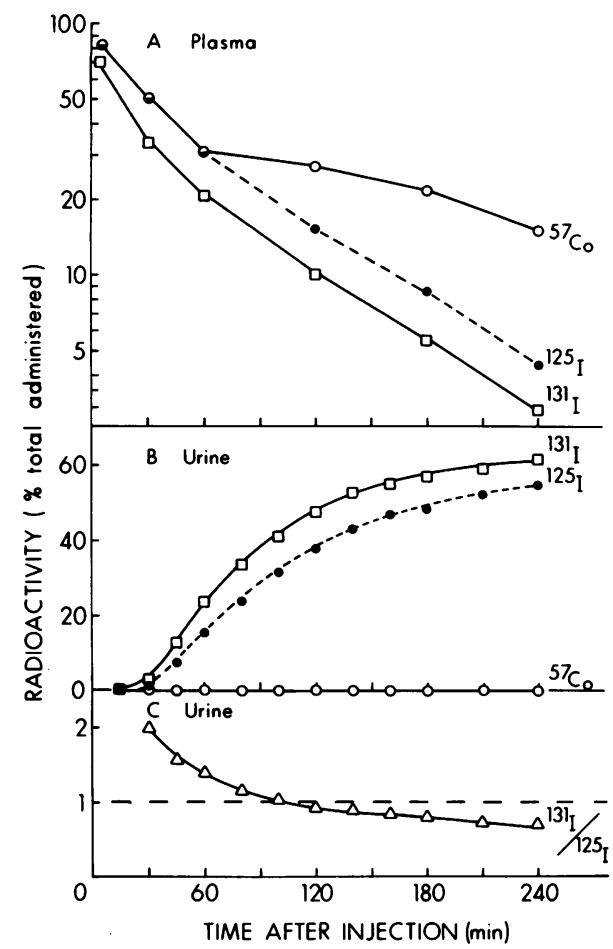

Figure 7 Plasma survival and cumulative urinary excretion of ${ }^{180} \mathrm{I},{ }^{67} \mathrm{Co}$, and ${ }^{181} \mathrm{I}$ and the ratio of ${ }^{189} \mathrm{I}$ to ${ }^{125} \mathrm{I}$ in individual urine samples after the simultaneous intravenous injection of ${ }^{125}$ I-labeled human TCII- $\left[{ }^{57} \mathrm{Co}\right] \mathrm{B}_{12}$ and ${ }^{181} \mathrm{I}-$ labeled human TCII devoid of $B_{12}$ into a rabbit. The experiment was performed as described in the legend to Fig. 2 , except that the plasma volume was calculated on the assumption that $82 \%$ of the $\left[{ }^{57} \mathrm{Co}\right] \mathrm{B}_{12}$ was present in the plasma $5 \mathrm{~min}$ after its injection. The value of $82 \%$ was the value observed in the experiment shown in Fig. 5 .

labeled $N$-succinimidyl-3-(4-hydroxyphenyl) propionate without causing significant alterations in the biological activities of these proteins. The labeled proteins retain their ability to bind $\mathrm{B}_{12}$, since the apo-proteins are adsorbed (more than $90 \%$ ) by $\mathrm{B}_{12}$-Sepharose, while the holo-proteins are not adsorbed (less than $10 \%$ ) by $\mathrm{B}_{12-}$ Sepharose. The labeled proteins also retain their ability to transport $B_{12}$ in vivo, since $B_{12}$ bound to the labeled proteins is cleared from rabbit plasma by tissues in a manner indistinguishable from that of $\mathrm{B}_{12}$ bound to the unlabeled native proteins. In the case of human TCII, it has also been possible to demonstrate that the plasma survival in rabbits of ${ }^{120}$ I-labeled human TCII-B口, based on the survival of the ${ }^{12 \pi} \mathrm{I}$ moiety, is indistinguishable from the survival of unlabeled human TCII- $B_{12}$, determined by a radioimmunoassay specific for human TCII, as opposed to rabbit TCII, since the anti-human TCII antibodies employed in the assay were raised in rabbits.

The availability of functional TCII- $B_{1}$ containing a covalently bound radioactive label on the protein moiety, in addition to a different radioactive label in the $B_{13}$ moiety, has enabled us to elucidate the role and fate of TCII in the plasma transport of Bis. The experiments employing ${ }^{120}$ I-labeled rabbit TCII- $\left[{ }^{87} \mathrm{Co}\right] \mathrm{B}_{19}$ indicate that the entire TCII-B $\mathrm{B}_{12}$ complex is cleared from rabbit plasma by a large number of tissues that include the kidney, liver, heart, lung, and spleen and the proximal, mid$\mathrm{dle}$, and distal portions of the small intestine. The TCII moiety appears to be degraded during this process since $30 \mathrm{~min}$ after the intravenous injection of ${ }^{185} \mathrm{I}$-labeled rabbit TCII- $\left[{ }^{57} \mathrm{Co}\right] \mathrm{B}_{12}$, the ratio of ${ }^{105} \mathrm{I}$ to ${ }^{87} \mathrm{Co}$ decreases progressively in all of the tissues studied and a form of ${ }^{125}$ I with a mol wt of less than 1,000 appears in the plasma and is rapidly excreted in the urine. That ${ }^{125} \mathrm{I}$ does not accumulate in excess of $\left[{ }^{57} \mathrm{Co}_{0} \mathrm{~B}_{12}\right.$ in any of the tissues studied suggests that the TCII moiety is degraded at the site of the initial tissue uptake of the TCII-B $B_{12}$ complex. These observations indicate that the TCII-facilitated transport of $\mathrm{B}_{12}$ differs considerably from the transferrin-facilitated transport of iron, since although transferrin transports iron rapidly to tissues ( $t_{3}$ of plasma survival of iron $=60-90 \mathrm{~min}$ ), the transferrin moiety has a prolonged plasma survival of 8-10 days (26).

The $\left[{ }^{87} \mathrm{Co}\right] \mathrm{B}_{19}$ moiety of ${ }^{180}$ I-labeled rabbit TCII$\left[{ }^{57} \mathrm{Co} \mathrm{B}_{19}\right.$ is cleared from rabbit plasma at the same rate as the ${ }^{125}$ I-labeled rabbit TCII moiety during the first

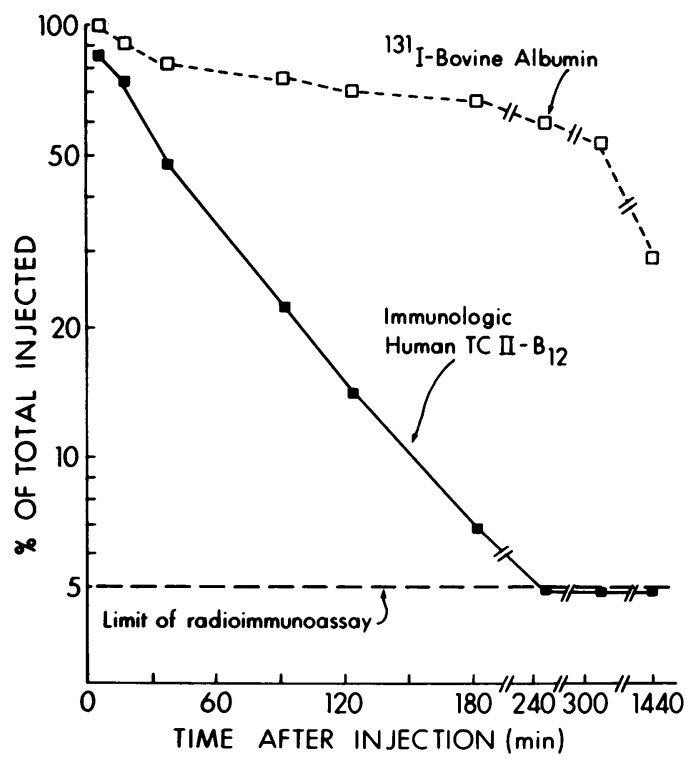

FIGURE 8 Plasma survival of ${ }^{181} \mathrm{I}$ and immunologic human TCII after the simultaneous intravenous injection of ${ }^{181} \mathrm{I}$ labeled bovine serum albumin and unlabeled human TCII$\mathrm{B}_{12}$ into a rabbit. The experiment was performed as described in the legend to Fig. 2. The injected sample contained homogeneous unlabeled human TCII saturated with $740 \mathrm{ng}$ of bound $\mathrm{B}_{12}$. Plasma samples were assayed for human TCII by a radioimmunoassay as described under Methods. 
$60 \mathrm{~min}$ after the intravenous injection of the complex, but at subsequent time periods the plasma ratio of $\left[{ }^{57} \mathrm{Co}\right] \mathrm{B}_{12}$ to ${ }^{125}$ I-labeled TCII increases progressively. This observation suggests that a significant portion of the $B_{12}$ reenters the plasma after its initial uptake by tissues. This phenomenon could explain the discrepancy between the rapid early and the slow late clearance of TCII- $\left[{ }^{57} \mathrm{Co}\right] \mathrm{B}_{12}$ from human plasma (see Introduction), although it should be emphasized that conclusions based on observations made in rabbits may not necessarily be valid for other species. It is also important to note that cyanocobalamin was employed in our studies, since different results might be found with hydroxo-, methyl-, or 5'deoxyadenosyl cobalamins.

Recent studies (13) employing ${ }^{120} \mathrm{I}$-labeled human granulocyte $\mathrm{B}_{12}$-binding protein- $\left[{ }^{57} \mathrm{Co}\right] \mathrm{B}_{12},{ }^{125} \mathrm{I}$-labeled human TCIII- $\left[{ }^{57} \mathrm{Co}\right] \mathrm{B}_{12}$, and ${ }^{125} \mathrm{I}$-labeled desialyzed human TCI- $\left[{ }^{57} \mathrm{Co}\right] \mathrm{B}_{12}$ have demonstrated that these glycoprotein- $\mathrm{B}_{12}$ complexes are cleared rapidly from rabbit plasma ( $t_{1}$ less than $5 \mathrm{~min}$ ) exclusively by the liver. Hepatic uptake is effected by the mechanism elucidated by Ashwell and Morell (14), in which glycoproteins containing terminal galactose residues bind to hepatocyte plasma membrane receptors, enter cells in intact form, presumably by pinocytosis, and are subsequently degraded by lysosomal enzymes. In the case of ${ }^{125} \mathrm{I}$-labeled $\mathrm{B}_{12}$-binding protein $\left[{ }^{57} \mathrm{Co}\right] \mathrm{B}_{12}$ complexes mentioned above, the ${ }^{125} \mathrm{I}$ reappears in the plasma in low-mol-wt (less than 1,000) form $30 \mathrm{~min}$ after hepatic uptake and is rapidly excreted in the urine, while $70-80 \%$ of the ${ }^{57} \mathrm{Co}$ reenters the plasma from 60 to $180 \mathrm{~min}$ after uptake and is present bound to rabbit TCII. The similarity between the kinetics of these phenomena and those observed with ${ }^{125}$ I-labeled TCII- $\left[{ }^{57} \mathrm{Co}\right] \mathrm{B}_{13}$ suggests that the entire TCII-B ${ }_{12}$ complex may be taken up by a variety of cells by pinocytosis and that the TCII moiety may be degraded subsequently by lysosomal enzymes. Evidence in support of this possibility has been obtained by Pletsch and Coffey $(27,28)$ in studies that involved the subcellular fractionation of rat liver at various times after the intravenous injection of $\left[{ }^{57} \mathrm{Co}\right] \mathrm{B}_{12}$ bound rapidly in vivo by rat plasma TCII. The availability of ${ }^{125} \mathrm{I}$-labeled TCII should enhance future studies of this kind.

The rapid turnover of TCII appears to place an unnecessary metabolic burden on the body, although it is important to note that this burden is relatively minor, since TCII accounts for only $0.0025 \%$ and $0.00005 \%$ of the total protein present in rabbit and human plasma, respectively. It is possible that TCII must be degraded to free the tightly bound $\mathrm{B}_{12}$ molecule (affinity constant $=10^{11} \mathrm{M}^{-1}$ [29]) for intracellular use, although protein degradation is not involved in the cellular uptake of iron from transferrin, despite the fact that the affinity constant for iron and transferrin is of the order of $10^{31} \mathrm{M}^{-1}$
(30). This explanation also appears unlikely since it would not account for the fact that apo-TCII is cleared from plasma and degraded actually slightly faster than holo-TCII. Rapid turnover of TCII, together with rapid recirculation of $B_{12}$, could be advantageous, in that it could be utilized as part of a mechanism to effect rapid changes in the amount of $B_{12}$ delivered to cells within the body.

\section{ACKNOWLEDGMENTS}

This work was supported by Grants AM 16668 and AM 05089 from the National Institutes of Health.

\section{REFERENCES}

1. Schneider, R. J., C. S. Mehlman, and R. H. Allen. 1974. The role of transcobalamin II in the plasma transport of vitamin $\mathrm{B}_{12}$. Blood. 44: 910. (Abstr.).

2. Scott, J. M., F. J. Bloomfield, R. Stebbins, and V. Herbert. 1974. Studies on the derivation of transcobalamin III from granulocytes. Enhancement by lithium and elimination by fluoride of in vitro increments in vitamin $\mathrm{B}_{12}$-binding capacity. J. Clin. Invest. 53: 228-239.

3. Gräsbeck, R. 1969. Intrinsic factor and other vitamin $\mathrm{B}_{12}$ transport proteins. Prog. Hematol. 6: 233-260.

4. Hall, C. A., and A. E. Finkler. 1971. Isolation and evaluation of the various $B_{12}$ binding proteins in human plasma. Methods Enzymol. 18(Part C) : 108-126.

5. Allen, R. H., and P. W. Majerus. 1972. Isolation of vitamin $\mathrm{B}_{12}$ binding proteins using affinity chromatography. III. Purification and properties of human plasma transcobalamin II. J. Biol. Chem. 247: 7709-7717.

6. Burger, R. L., C. S. Mehlman, and R. H. Allen. 1975. Human plasma $R$-type vitamin $\mathrm{B}_{12}$ binding proteins. I. Isolation and characterization of transcobalamin I, transcobalamin III, and the normal granulocyte vitamin $B_{12}$ binding protein. J. Biol. Chem. 250: 7700-7706.

7. Allen, R. H., and P. W. Majerus. 1972. Isolation of vitamin $B_{12}$ binding proteins using affinity chromatography. II. Purification and properties of a human granulocyte vitamin $\mathrm{B}_{12}$ binding protein. J. Biol. Chem. 247: 7702-7708.

8. Burger, R. L., and R. H. Allen. 1974. Characterization of vitamin $\mathrm{B}_{12}$-binding proteins isolated from human milk and saliva by affinity chromatography. J. Biol. Chem. 249: 7220-7227.

9. Burger, R. L., S. Waxman, H. S. Gilbert, C. S. Mehlman, and R. H. Allen. 1975. Isolation and characterization of a novel vitamin $\mathrm{B}_{12}$-binding protein associated with hepatocellular carcinoma. J. Clin. Invest. 56: $1262-1270$.

10. Stenman, U.-H. 1974. Amniotic fluid vitamin $B_{12}$-binding protein. Purification and characterization with isoelectric focusing and other techniques. Biochim. Biophys. Acta. 263: 173-184.

11. Benson, R. E., M. E. Rappazzo, and C. A. Hall. 1972. Late transport of vitamin $\mathrm{B}_{12}$ by transcobalamin II. $J$. Lab. Clin. Med. 80: 488-495.

12. Hom, B. L., and H. A. Olesen. 1969. Plasma clearance of ${ }^{57}$ Cobalt-labelled vitamin $B_{12}$ bound in vitro and in vivo to transcobalamin I and II. Scand. J. Clin. Lab. Invest. 23 : 201-211.

13. Burger, R. L., R. J. Schneider, C. S. Mehlman, and R. H. Allen. 1975. Human plasma R-type vitamin $B_{12}$ binding proteins. II. The role of transcobalamin I, trans- 
cobalamin III, and the normal granulocyte vitamin $B_{12}$ binding protein in the plasma transport of vitamin $\mathbf{B}_{12}$. J. Biol. Chem. 250 : 7707-7713.

14. Ashwell, G., and A. G. Morell. 1974. The role of surface carbohydrates in the hepatic recognition and transport of circulating glycoproteins. Adv. Enzymol. 41: 99-128.

15. Carmel, R., and V. Herbert. 1969. Deficiency of vitamin $\mathrm{B}_{12}$-binding alpha globulin in two brothers. Blood. 33: 1-12.

16. Cooper, B. A., and W. Paranchych. 1961. Selective uptake of specifically bound cobalt-58 vitamin $\mathrm{B}_{12}$ by human and mouse tumor cells. Nature (Lond.). 191: 393-395.

17. Retief, F. R., C. W. Gottlieb, and V. Herbert. 1966. Mechanism of vitamin $\mathrm{B}_{12}$ uptake by erythrocytes. $J$. Clin. Invest. 45 : 1907-1915.

18. Finkler, A. E., and C. A. Hall. 1967. Nature of the relationship between vitamin $B_{12}$ binding and cell uptake. Arch. Biochem. Biophys. 120: 79-85.

19. Ryel, E. M., L. M. Meyer, and R. A. Gams. 1974. Uptake and subcellular distribution of vitamin $B_{12}$ in Mouse L1210 leukemic lymphoblasts. Blood. 44: 427-433.

20. Rosenberg, L. E., A. Lilljequist, and R. H. Allen. 1973. Transcobalamin II-facilitated uptake of vitamin $B_{12}$ by cultured fibroblasts: studies in methylmalonicaciduria. J. Clin. Invest. 52: 69a-70a. (Abstr.).

21. Hakami, N., P. E. Neiman, G. P. Cannellos, and J. Lazerson. 1970. Neonatal megaloblastic anemia due to inherited transcobalamin II deficiency in two siblings. N. Engl. J. Med. 285: 1163-1170.

22. Hall, C. A., and A. E. Finkler. 1965. The dynamics of transcobalamin II. A vitamin $B_{12}$ binding substance in plasma. J. Lab. Clin. Med. 65: 459-468.

23. Bolton, A. E., and W. M. Hunter. 1973. The labelling of proteins to high specific radioactivities by conjugation to a ${ }^{125}$ I-containing acylating agent. Application to the radioimmunoassay. Biochem. J. 133: 529-539.

24. Allen, R. H., and C. S. Mehlman. 1973. Isolation of gastric vitamin $\mathrm{B}_{12}$ binding proteins using affinity chromatography. I. Purification and properties of human intrinsic factor. J. Biol. Chem. 248: 3660-3669.

25. Allen, R. H., and P. W. Majerus. 1972. Isolation of vitamin $\mathrm{B}_{12}$-binding proteins using affinity chromatography. I. Preparation and properties of vitamin $B_{12-}$ Sepharose. J. Biol. Chem. 247: 7695-7701.

26. Awai, M., and E. B. Brown. 1963. Studies of the metabolism of $\mathrm{I}^{132}$-labeled human transferrin. J. Lab. Clin. Med. $61: 363-396$.

27. Pletsch, Q. A., and J. W. Coffey. 1971. Intracellular distribution of radioactive vitamin $\mathrm{B}_{12}$ in rat liver. $J$. Biol. Chem. 246: 4619-4629.

28. Pletsch, Q. A., and J. W. Coffey. 1972. Properties of the proteins that bind vitamin $B_{12}$ in subcellular fractions of rat liver. Arch. Biochem. Biophys. 151: 157-167.

29. Hippe, E., and H. Olesen. 1971. Nature of vitamin $B_{18}$ binding. III. Thermodynamics of binding to human intrinsic factor and transcobalamins. Biochim. Biophys. Acta. 243: 83-89.

30. Aasa, R., B. G. Malmström, P. Saltman, and T. Vänngård. 1963. The specific binding of iron (III) and copper (II) to transferrin and conalbumin. Biochim. Biophys. Acta. 75 : 203-222. 